\title{
Sol-Gel Fabricated CuO Thin Film: Characterization for Device Application
}

\author{
A. Maini*, M.A. Shah ${ }^{\dagger}$ \\ Special Laboratory for Multifunctional Nanomaterials (SLMN), P.G Department of Physics, National Institute of \\ Technology Srinagar, Hazratbal-Srinagar, J\&K 190006, India
}

(Received 06 November 2020; revised manuscript received 20 October 2021; published online 25 October 2021)

\begin{abstract}
In this paper, a wide band gap semiconductor $\mathrm{CuO}$ has appeared as a promising material suitable for high-temperature, high-frequency, and high-power operations in electronics as well as optoelectronic devices because of its exceptional characteristics. In particular, $\mathrm{CuO}$ films have an outstanding ability to materialize short-wavelength light-emitting devices due to the large band gap energy. $\mathrm{CuO}$ films are widely used for optoelectronic applications in the short wavelength visible light region especially for laser diodes (LDs) and light-emitting diodes (LEDs). Here, we report the properties of a copper oxide thin film prepared by the sol-gel technique, which is very economical and involves a sophisticated method. The prepared film is characterized by X-ray diffraction (XRD) for structural analysis. The scanning electron microscope identifies porous morphology, and the elemental composition of $\mathrm{CuO}$ is confirmed by EDS. The appearance of strong and weak Raman peaks at $300-350 \mathrm{~cm}^{-1}$ is observed. The optical study is carried out by UV-visible absorbance from the direct band gap calculated for the prepared film, that is $2.43 \mathrm{eV}$. The $I$ - $V$ measurements are performed using a two-probe technique, and the $\mathrm{CuO}$ film shows semiconductor behavior with an activation energy of $0.21 \mathrm{eV}$. Thus, the obtained results indicate the prepared sample for electronic devices and various other optical applications.
\end{abstract}

Keywords: CuO, Sol-gel, Optical band gap, Nanoparticles, DC conductivity, Optoelectronic.

\section{INTRODUCTION}

Transition metal oxides (TMOs) have become an essential part of modern technologies that demand both electrical and optical transparency in the visible domain of the electromagnetic spectrum [1]. The thin film based copper oxide $(\mathrm{CuO})$ has been used in many electronic and optoelectronic devices such as thin-film transistors, cross-point memories, gas sensors, and lithium-ion batteries [2] over recent decades. The main advantages of this oxide include low production cost, thermal stability, nontoxicity, and relatively high optical absorption [3]. $\mathrm{CuO}$ is a degenerate $p$-type II-VI semiconductor possessing special features such as high electrical conductivity (even without doping), high optical transmittance, exceptional luminescence characteristics, and an optical energy band gap of $2.13 \mathrm{eV}$ [4]. Nowadays, studies of copper oxide $(\mathrm{CuO})$ nanoparticles continue due to their $p$-type semi-conducting properties with a narrow band gap, monoclinic structure, and giant magnetic field resistance [5].

Various deposition techniques have been deployed for the preparation of $\mathrm{CuO}$ thin films, such as chemical vapor deposition [6], magnetron sputtering [7], thermal oxidation [8], electrodeposition [9], sol-gel [10], and spray pyrolysis [11]. In this paper, we report the synthesis and characterization of $\mathrm{CuO}$ thin films by a simple sol-gel dip-coating technique. In contrast to other methods, the sol-gel dip-coating technique has distinct advantages such as simplicity, cost-effectiveness, ecofriendliness and high porosity over a large area. To our best knowledge, the sol-gel dip-coating has not been implemented for any TMO film preparation. We have investigated the XRD, optical and electrical properties of $\mathrm{CuO}$ thin films prepared by this simple technique for optoelectronic applications.

\section{EXPERIMENTAL}

Initially, a gel solution made of copper nitrate $\left(\mathrm{Cu}\left(\mathrm{NO}_{3}\right)_{2}\right) 5 \mathrm{H}_{2} \mathrm{O}$ and citric acid $\left(\mathrm{C}_{6} \mathrm{H}_{8} \mathrm{O}_{6}\right)$ with a molar ratio of 1:3.6 was prepared. Next, the as-prepared solution was continuously stirred at a temperature of $70^{\circ} \mathrm{C}$ for half an hour. Then, the solution was heated at a temperature of $100{ }^{\circ} \mathrm{C}$ until it is converted into a dry powder. Further, the sample was annealed at a temperature of $200^{\circ} \mathrm{C}$ for $1 \mathrm{~h}$ to reduce grain boundaries. Finally, the obtained powder was calcined at a temperature of $500{ }^{\circ} \mathrm{C}$ for $5 \mathrm{~h}$ to remove impurities. The obtained calcined powder was found to be a good crystalline $\mathrm{CuO}$ phase. The process is shown in Fig. 1a. Prior to sol-gel dip-coating, glass substrates were cleaned with a mild soap solution and thoroughly rinsed with distilled water followed by boiled water. Finally, the glass substrates were immersed into the solution as shown in Fig. 1b. The films thus prepared were inserted into a muffle furnace and kept at $300{ }^{\circ} \mathrm{C}$ for $10 \mathrm{~min}$ in order to evaporate the organic material. Fig. 1c depicts the required stable film.

All the characteristic measurements were carried out at room temperature in air. The characterization techniques such as X-ray diffraction (XRD), Raman spectroscopy, UV-Vis spectroscopy, and Scanning Electron Microscope (SEM) were used to confirm the formation of $\mathrm{CuO}$ and effect of doping on its structural and morphological features.

*anilmaininitsri@gmail.com

$\dagger$ shah@nitsri.ac.in 


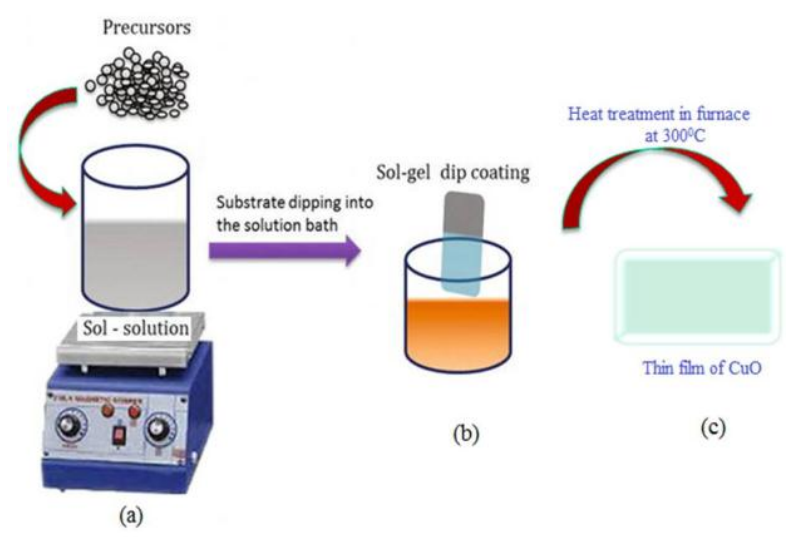

Fig. 1 - Schematic diagram for the preparation of a thin film of $\mathrm{CuO}$ by the sol-gel technique

\section{RESULTS AND DISCUSSION}

\subsection{XRD Pattern}

XRD pattern is the most suitable technique to identify the crystalline nature of the prepared samples. The XRD pattern of the thin film is shown in Fig. 2. All the peaks could be clearly indexed to the monoclinic phase with lattice constants $a=0.4675, b=0.3418, c=0.5095$, which agrees well with the literature. In addition, the XRD pattern shows that the copper oxide is crystalline in nature and the diffraction peaks match very well with the pdf file (JCPDS-05-0661). The peaks at $2 \theta=32.51^{\circ}, 35.33^{\circ}, 38.01^{\circ}, 49^{\circ}, 53.88^{\circ}, 58.93^{\circ}, 62.11^{\circ}$, $66.51^{\circ}, 68.78^{\circ}, 72.68^{\circ}, 75.53^{\circ}$ are assigned to the (110), (-111), (111), (- 202), (020), (202), (-113), (022), (220), (321), and (203) reflection lines of monoclinic $\mathrm{CuO}$ particles, respectively. No characteristic peaks of any impurities are detected except for a few traces of copper. The crystallite size is calculated from the DebyeScherrer formula:

$$
D=(K \lambda / \beta \operatorname{Cos} \theta)
$$

where $K$ is the shape factor equal to $0.94, \lambda$ is the $\mathrm{CuKa}$ radiation wavelength $(1.5406 \AA), \beta$ refers to the full width half maximum (FWHM) in radians, and $\theta$ is the angle of incident radiation, which is $34.96 \mathrm{~nm}$.

To get more crystal quality information, dislocation density $(\delta)$ must be determined according to the relation (2) and is about $8.18 \cdot 10^{18}$ lines $/ \mathrm{m}^{2}$ [12]:

$$
\Delta=\left(1 / D^{2}\right) .
$$

In thin films, strain originates mainly from the mismatch between a polycrystalline film and an amorphous substrate or from the difference in the thermal expansion coefficients of the film and the substrate. Microstrain can be calculated by the following formula and is found to be equal $1.037 \cdot 10^{3}$ lines $^{-2} / \mathrm{m}^{4}[13]$ :

$$
\varepsilon=\beta \cos \theta / 4 \text {. }
$$

The above structural parameters are in good agreement with reported values of Basith et al. [14].

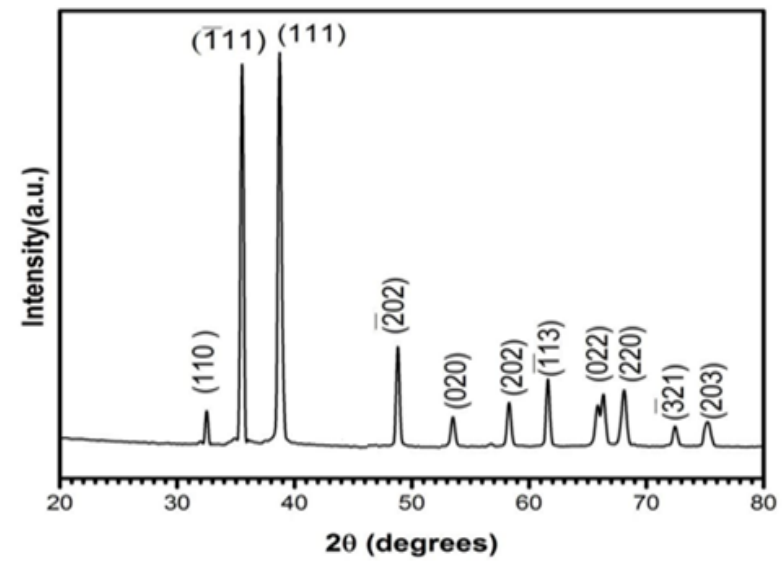

Fig. 2 - XRD pattern of $\mathrm{CuO}$ thin film

\subsection{Morphology and Elemental Examination}

The as-synthesized samples were directly transferred to the FESEM chamber without disturbing the original nature of the products. Fig. 3 shows the morphology of nanoclusters obtained after the reaction of copper with water at $120^{\circ} \mathrm{C}$ for $18 \mathrm{~h}$. The nanoclusters constituting of nanocrystals are almost spherical in shape and have diameters varying between 15 to $25 \mathrm{~nm}$, with an average diameter of $15 \mathrm{~nm}$. In some regions, we notice that large nanoparticles (with an average diameter of $40 \mathrm{~nm}$ ) are surrounded by smaller nanoparticles. In addition, the EDS spectrum revealed only the elements $\mathrm{Cu}$ and $\mathrm{O}$, and the atomic ratio of $\mathrm{Cu}$ to $\mathrm{O}$ was $1: 1$, which was consistent with stoichiometric $\mathrm{CuO}$. This EDS spectrum is shown in Fig. 4.

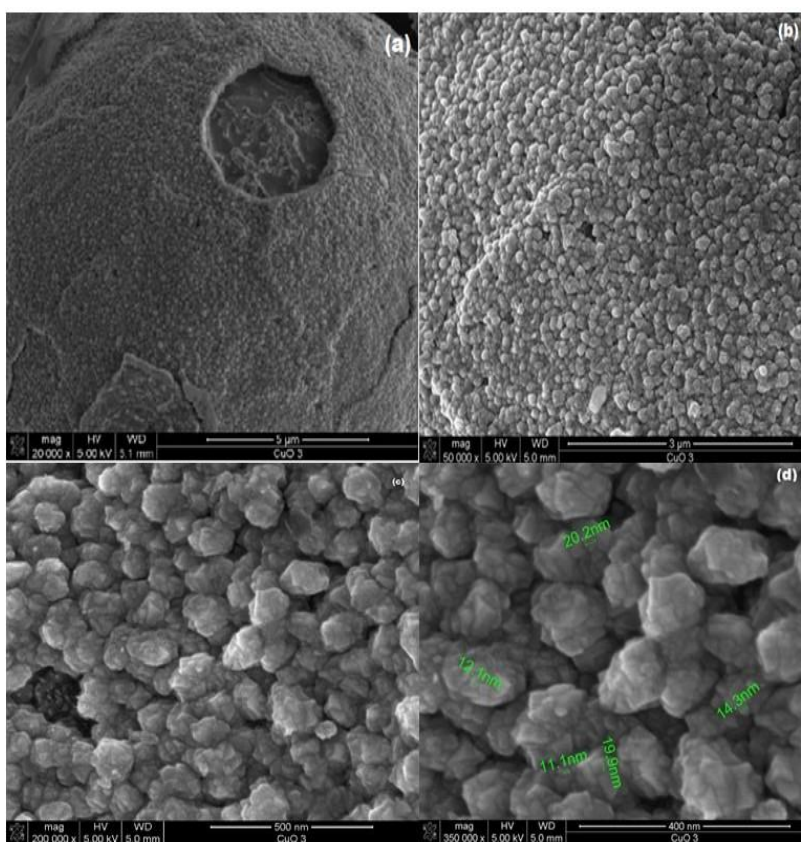

Fig. 3 - FESEM images of $\mathrm{CuO}$ thin film prepared at $300{ }^{\circ} \mathrm{C}$ with different magnifications 


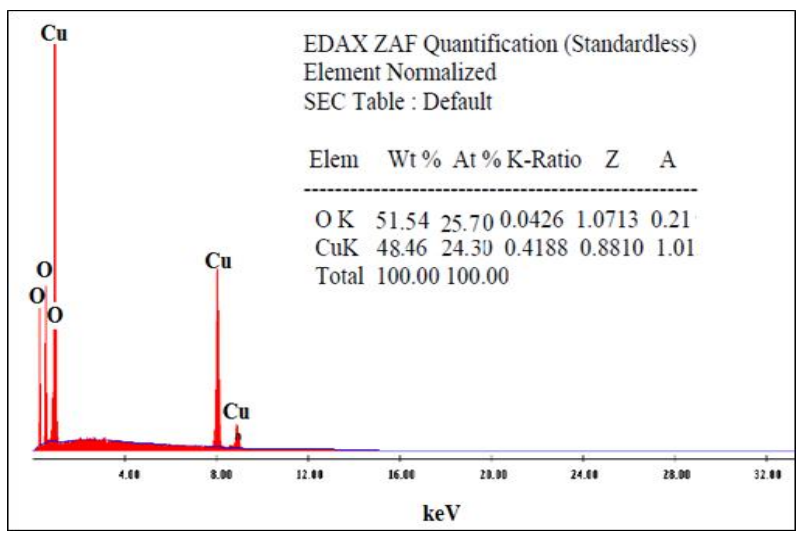

Fig. 4 - EDS pattern of $\mathrm{CuO}$ thin film

\subsection{Raman Spectroscopy}

Raman spectroscopy is a good complementary method to determine the film phase structure in the surface vicinity. Here, Raman analysis of $\mathrm{CuO}$ thin film at room temperature $\left(300{ }^{\circ} \mathrm{C}\right)$ was carried out. $\mathrm{CuO}$ has a monoclinic structure with space group symmetry of $\mathrm{C}_{2 \mathrm{~h}}{ }^{6}$. It has 12 phonon branches: four atoms in the primitive cell (four $\mathrm{Cu}-\mathrm{O}$ molecules per unit cell and two $\mathrm{CuO}$ units in the primitive cell). A factor-group analysis gives the following zone-center modes [15]:

$$
\Gamma_{v i b}=A_{g}+2 B_{g}+4 A_{u}+5 B_{u} .
$$

Fig. 5 revealed three Raman active modes at 283, 330 and $616 \mathrm{~cm}^{-1}$. The peak at $283 \mathrm{~cm}^{-1}$ corresponds to the $A_{g}$ mode, and the other two peaks at 330 and $616 \mathrm{~cm}^{-1}$ correspond to two $B_{g}$ modes, which are the basic band of $\mathrm{CuO}$ [16]. In both XRD and Raman, the $\mathrm{CuO}$ peaks were identified.

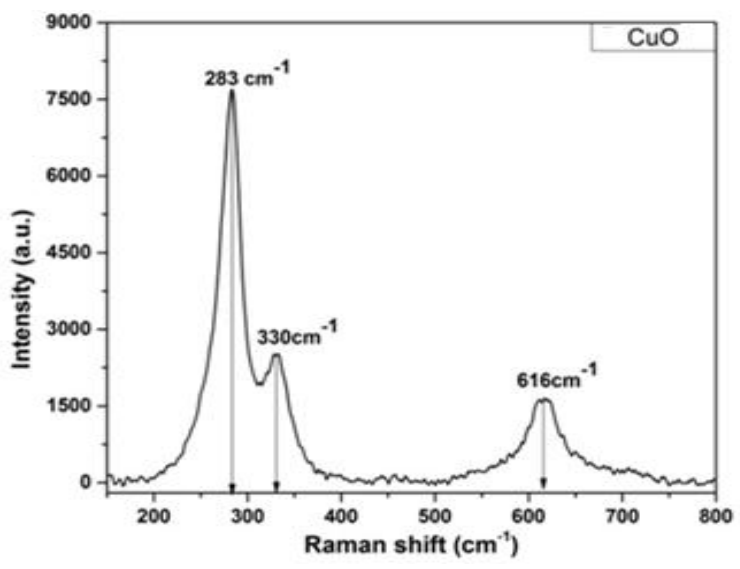

Fig. 5 - Raman spectra of $\mathrm{CuO}$ thin film

\subsection{FTIR Analysis of CuO Thin Film}

FTIR spectroscopy, a phenotypic technique, identifies chemical bonds in a molecule by producing an infrared absorption spectrum. It is an effective analytical instrument for detecting functional groups, intra/inter molecular interactions via hydrogen bonding and molecular geometry [17]. The infrared spectrum of $\mathrm{CuO}$ film is shown in Fig. 6. This spectrum of $\mathrm{CuO}$ sample is presented in three regions. In the first region, the peaks observed at 523 and $856 \mathrm{~cm}^{-1}$ represent a strong absorption band. In this band, the stretching of $\mathrm{Cu}-\mathrm{O}$ is along the $(-202)$ direction because $\mathrm{CuO}$ is monoclinic in phase [18]. In the second region $\left(1435-1636 \mathrm{~cm}^{-1}\right)$, the peaks can be attributed to the presence of $\mathrm{CO}_{2}$ in air. The third region starts from 2948 to $3513 \mathrm{~cm}^{-1}$, and moistening in air and hydrated $\mathrm{CuO}$ material are responsible for the creation of peaks. Therefore, the results of the FTIR spectrum confirm that synthesized $\mathrm{CuO}$ thin film dipped into the solution is a pure and monolithic phase.

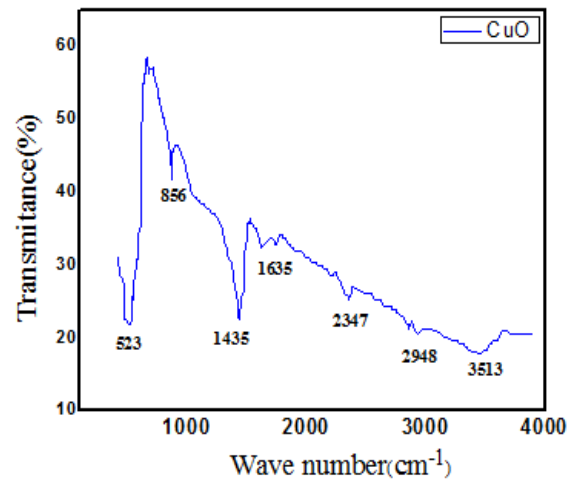

Fig. 6 - FTIR spectrum of $\mathrm{CuO}$ thin film

\section{5 $\quad 3.5$ UV-Visible}

The optical properties and the energy band gap of $\mathrm{CuO}$ thin film were studied by UV-visible absorbance spectroscopy in the wavelength range $250-1100 \mathrm{~nm}$, as shown in Fig. 7. This spectrum shows the excitonic absorption edge at $553 \mathrm{~nm}$ for the film as prepared. The corresponding band gap energy $\left(E_{g}\right)$ for the given film is determined using the Einstein's equation (5) [19]:

$$
\begin{gathered}
E_{g}=\frac{h c}{\lambda s}, \\
E_{g}=\frac{1240}{\lambda_{s}} e V,
\end{gathered}
$$

where $h$ is the Planck's constant, $c$ is the velocity of light, and $\lambda_{s}$ is the excitonic absorption edge. The energy band gap is calculated to be $\sim 2.25 \mathrm{eV}$. This value is suitable for optoelectronics devices like LEDs, solar cells, sensors etc.

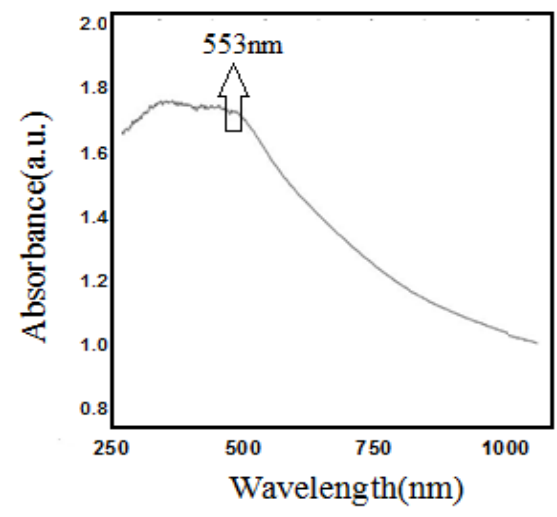

Fig. 7 - Absorbance spectrum of $\mathrm{CuO}$ thin film 


\subsection{Electrical Conduction}

Electrical characterization plays the main role in the identification of photovoltaic materials, and in this report, the DC resistivity measurement of the fabricated $\mathrm{CuO}$ film was carried out using a Keithley 4200 semiconductor characterization system. It was observed that the $\mathrm{CuO}$ film has a high resistivity due to grain boundary effects and a larger band gap of $\mathrm{CuO}$, which will create a potential barrier that causes a reduction in conductivity [20]. The temperature dependence of dark electrical resistivity (DC) can be depicted using the popular Arrhenius relation given by:

$$
\rho=\rho_{0} \cdot \exp \left(\frac{E_{a}}{k T}\right)
$$

where $\rho_{0}, E_{a}, k$ and $T$ are the pre-exponential factor, activation energy, Boltzmann constant, and temperature in Kelvin, respectively. The activation energy for $\mathrm{CuO}$ fabricated film was calculated from the slope of the graph shown in Fig. 8. The activation energy was found to be $0.21 \mathrm{eV}$, which is a suitable value for optoelectronic applications.

\section{CONCLUSIONS}

A thin film of $\mathrm{CuO}$ on a glass substrate was prepared on a home-made sol-gel syringe pyrolysis unit. XRD showed that the film has a monoclinic crystal structure with the lattice parameters $a=0.4675 \AA$, $b=0.3418 \AA$, and $c=0.5095 \AA$. According to the XRD pattern, the material thus prepared is in single $\mathrm{CuO}$ phase with preferential orientation along the (111) plane. The Raman spectra are in good agreement with the XRD. The average grain size was found to be about

\section{REFERENCES}

1. A. Bhaumik, A. Haque, P. Karnati, M.F.N. Taufique, R. Patel, K. Ghosh, Thin Solid Films. 572, 126 (2014).

2. A. Maini, M.A. Shah, Int. J. Ceramic. Eng. Sci. 3, 192 (2021).

3. H. Deng, H.-R. Li, F. Wang, C.-X. Yuan, S. Liu, P. Wang, L.Z. Xie, Y.Z. Sun, F.Z. Chang, J. Mater. Sci. Mater. Electron. 27, 6766 (2016).

4. J.F. Xu, W. Ji, Z.X. Shen, S.H. Tang, X.R. Ye, D.Z. Jia, X.Q. Xin, J. Solid State Chem. 147, 516 (1999).

5. S. Rehman, A. Mumtaz, S.K. Hasanain, J. Nanopart. Res. 13, 2497 (2011).

6. G. Wang, X. Shen, J. Horvat, B. Wang, H. Liu, D. Wexler, Jane Yao, J. Phys. Chem. C 113 No 11, 4357 (2009).

7. C.C. Hsu, C.-H. Wu, S.-Y. Wang, J. Alloy. Compd. 663, 262 (2016).

8. A.D. Faisal, W.K. Khalef, J. Mater. Sci. Mater. Electron. 28, 18903 (2017)

9. B. Yan, Y. Wang, T. Jiang, X. Wu, J. Mater. Sci. Mater. Electron. 27, 5389 (2016)

10. D.M. Jundale, P.B. Joshi, S. Sen, V.B. Patil, J. Mater. Sci. Mater. Electron. 23, 1492 (2012)

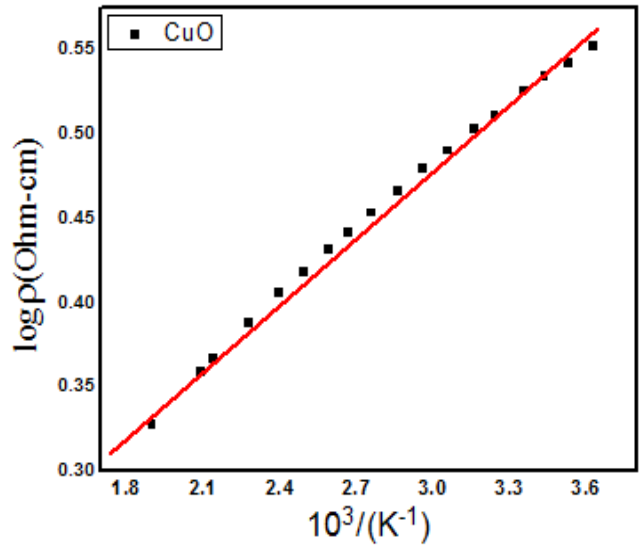

Fig. 8 - Linear fit of temperature-dependent resistivity of $\mathrm{CuO}$ thin film

$34.96 \mathrm{~nm}$. The optical band gap of the material was found to be $2.25 \mathrm{eV}$. The FTIR spectrum confirmed the $\mathrm{Cu}-\mathrm{O}$ stretching modes without any trace of impurities. The DC conductivity measurement revealed the semiconducting behavior of the film with an activation energy of $0.21 \mathrm{eV}$. This showed that the charge conduction process is thermally activated. The present study applied the quality of $\mathrm{CuO}$ thin films prepared by this technique to be used in optoelectronic devices.

\section{ACKNOWLEDGEMENTS}

The authors are thankful to BGSB University for the support and encouragement, as well as to Dr. A.H. Sofi from the Department of Physics at Central University of Kashmir for helpful suggestions.

11. J. Morales, L. Sa'nchez, F. Martı́n, J.R. Ramos-Barrado, M. Sa'nchez, Thin Solid Films 474, 133 (2005).

12. M. Manickam, V. Ponnuswamy, C. Sankar, R. Sureh, Optik 127, 5278 (2016)

13. R.A. Zargar, M.A. Bhat, H.A. Reshi, S.D. Khan, Result. Phys. 9, 1673 (2018).

14. N.M. Basith, J.J. Vijaya, L.J. Kennedy, M. Bououdina, S. Hussain, J. Nanosci. Nanotechnol. 14 No 3, 2577 (2014).

15. C. Abinaya, K. Bethke, V. Andrei, J. Baumann, B.P. Herrmann, B. Kanngießer, B. Beckhoff, G.C. Vásquez, J. Mayandi, T.G. Finstad, K. Rademann, RSC Adv. 10, 29394 (2020).

16. H.F. Goldstein, D.S. Kim, Y.Y. Peter, Phys. Rev. B 41, 7192 (1990).

17. R.A. Zargar, M. Arora, R.A. Bhat, J. Appl. Phys. A 124, 36 (2018).

18. R.M. Mohamed, F.A. Harraz, A. Shawky, Ceram. Int. 40, 2127 (2014).

19. R.A. Zargar, M.M. Hassan, N. Boora, I. Ahmed, S. Ahmed, K.U. Nissa, S. Kumari, A.K. Hafiz, Int. J. Ceram. Eng. Sci. 2, 169 (2020).

20. Y Kajikawa, J. Appl. Phys. 114, 053707 (2013). 


\title{
Тонка плівка СuО, виготовлена методом золь-гелю: характеристики для застосування в пристроях
}

\author{
A. Maini, M.A. Shah \\ Special Laboratory for Multifunctional Nanomaterials (SLMN), P.G Department of Physics, National Institute of \\ Technology Srinagar, Hazratbal-Srinagar, J\&K 190006, India \\ Широкозонний напівпровідник $\mathrm{CuO}$ е перспективним матеріалом, придатним для високо- \\ температурних, високочастотних та високопотужних застосувань в електроніці і оптоелектронних \\ пристроях через свої виняткові характеристики. Зокрема, на основі плівки СuО реалізуються корот- \\ кохвильові світловипромінювальні пристрої завдяки великій ширині забороненої зони. Плівки СuО \\ широко використовуються для оптоелектронних застосувань у короткохвильовій частині видимого сві- \\ тла, особливо для лазерних діодів та світлодіодів. У роботі ми повідомляемо про властивості тонкої \\ плівки з оксиду міді $\mathrm{CuO}$, виготовленої дуже економічною технікою золь-гелю. Підготовлена плівка \\ характеризуеться рентгенівською дифракцією (XRD) для структурного аналізу. Скануючий електрон \\ ний мікроскоп визначає пористу морфологію, а елементний склад $\mathrm{CuO}$ підтверджується EDS. Cпосте- \\ рігається поява сильних і слабких раманівських піків у діапазоні 300-350 см-1. Оптичне дослідження \\ проводиться за допомогою поглинання в УФ та видимій областях з прямої забороненої зони, розрахо- \\ ваної для підготовленої плівки, яка становить 2,43 еВ. Вимірювання характеристик $I$ - $V$ виконуються \\ за двозондовою технікою, а плівка $\mathrm{CuO}$ демонструє напівпровідникову поведінку з енергією активаціі \\ 0,21 еВ. Таким чином, отримані результати вказують на можливість використання СuО в електрон- \\ них пристроях та різних інших оптичних застосуваннях
}

Ключові слова: $\mathrm{CuO}$, Золь-гель, Оптична ширина забороненої зони, Наночастинки, Провідність за постійним струмом, Оптоелектронний. 